\title{
ANTITRUST POLICIES AND THE NEW ATTACK ON THE FEDERAL TRADE COMMISSION
}

\author{
Robert A. Wallace* and Paul H. Dodglas $†$
}

$Q^{1}$ INCE THE PASSAGE OF THE SHERMAN ACT ${ }^{1}$ in 1890 the enforcement of antitrust laws has been the subject of recurring debate. On the one side are those who insist on a more vigorous enforcement. On the other side, we find those who think that enforcement is going too far. As one of the two policemen in the antitrust field, the Federal Trade Commission has not escaped this debate, and recent years have seen it attacked from both sides and from the inside as well. The sentiment of those believing that the FTC has enforced antimonopoly laws too vigorously has recently crystallized into a new attack which has as its goal the outright abolition of the FTC as an antimonopoly agency.

The new attack on the FTC has not as yet developed into a public relations type of an all-out campaign. But it has been launched in a recent issue of the University of Chicago Law Review by William Simon ${ }^{2}$ who is closely identified with the leadership of the "less enforcement" forces. Mr. Simon is a student of the antitrust laws and has had unusual practical experience with these laws. $\mathrm{He}$ is, moreover, sincere in his convictions that some of these laws have unnecessarily interfered with established business practices. His views merit attention, but it is our hope to express our side of the issues so that it may be considered along with his.

Mr. Simon has variously been (1) a leader in the "Council for Clarification of Pricing Practices,"3 the main group registered with the Secretary of the Senate actively supporting the several basing point bills introduced in the 81st and 82d Congresses; (2) General Counsel of a special Senate Interstate and Foreign Commerce Subcommittee on Pricing established by a Senate resolution ${ }^{4}$ in 1948 , to investigate the effects of the Cement de-

* Legislative Assistant to Senator Paul H. Douglas, formerly Instructor of PoliticalScience, Illinois Institute of Technology.

$\dagger$ United States Senator from Tllinois, formerly Professor of Economics, University of Chicago.

${ }^{1} 26$ Stat. 209 (1890), as amended, 15 U.S.C.A. $\$ 1$ (1951).

2 Simon, The Case Against the Federal Trade Commission, 19 Univ. Chi. L. Rev. 297 (1952).

396 Cong. Rec. 4598 (1950).

${ }^{4}$ Senate Interstate and Foreign Commerce Subcommittee on Pricing, known as the Capehart Committee in the 80th Congress. Senator Capehart introduced Sen. Res. 241 in the 80th Cong. 1st Sess. (1948), to investigate the impact of the Cement decision on consumers and business. This resolution was referred to the subcommittee which he headed. Before any report 
cision upon business and consumers; (3) Counsel for respondents in various FTC cases, including the Spark Plug cases ${ }^{5}$ now pending before the Commission; and (4) amicus curiae opposing the FTC in Standard Oil (Indiana) Company v. FTC. ${ }^{6}$ The fact that both the Council and the Senate Subcommittee have been unsuccessful in their attempts to pass bills which, in the authors' judgments, would water down two of the antimonopoly laws enforced by the Commission, may possibly indicate that Simon's proposals are the harbinger of a new concerted push to change these laws.

Mr. Simon finds fault with the Commission on a number of grounds, including (1) that it has failed to be informative, (2) that it has created confusion with respect to the antitrust laws, and (3) that the Commission staff has pursued "unorthodox ideologies." He recommends (1) transferring the FTC antitrust functions to the Department of Justice, (2) transferring its economic investigations to the Department of Commerce, and (3) providing that Commission findings of fact be subject to review on the "weight of evidence."

Actually, this new attack on the Commission is a continuation, in a somewhat modified form, of the same attacks which have been waged continuously since the Supreme Court decision in FTC v. Cement Institute ${ }^{7}$ in April of 1948. The only thing really new about the present attack is that it attempts to consolidate the standard criticisms of those demanding less enforcement with certain criticisms which have been made by those with an opposite point of view. And it ends with proposals with which the latter would be the last to agree.

Therefore, to evaluate the new attack, we must first establish the cast of main characters, and distinguish, at least in a general way, their various grounds for criticism. And since the criticisms are leveled at the Commission's enforcement-or lack of enforcement-of certain of the antimonop-

could be made on the original Capehart resolution, Senator Johnson succeeded Senator Capehart as Chairman on January 3,1949. On January 5, 1949, the two Senators introduced Sen. 236, a bill to make permanent amendments to the FTC Act and the Clayton Act, as amended by the Robinson-Patman Act. The bill was referred to the Committee on Interstate and Foreign Commerce, which proceeded, through the subcommittee headed by Senator Johnson, of which Simon was counsel, to hold three days of hearings in January and one day in February. The February hearing was held for the purpose of amending Sen. 236 before transferring jurisdiction over the bill to the Senate Committee on the Judiciary, to which had also been referred Sen. 1008, a bill providing for a two-year legislative moratorium on basing point cases.

5 Champion Spark Plug Co., FTC Doc. No. 3977; General Motors Corp., FTC Doc. No. 5620; The Electric Auto-Lite Co., FTC Doc. No. 5624.

B FTC Doc. No. 4389, 41 F.T.C. 263 (1945), modified, 43 F.T.C. 56 (1946), aff'd, 173 F. 2d 210 (C.A. 7 th, 1949), rev'd, 340 U.S. 231 (1951).

${ }^{7}$ FTC Doc. No. 3167, rev'd, 157 F. 2 d 533 (C.A. 7th, 1946), rev'd, 333 U.S. 683 (1948). 
oly laws, we must identify these laws and consider what the business practices are that these laws have embarrassed. Finally, we shall comment upon Mr. Simon's main charges and recommendations.

\section{The Cast of Characters}

Probably the most authoritative critics of the FTC in recent years, who want more vigorous enforcement of the antitrust laws, are (1) the Select Committee on Small Business of the House of Representatives, headed by Congressman Wright Patman of Texas, (2) The Hoover Commission Task Force on Regulatory Commissions, and (3) Honorable James $M$. Landis, a noted public servant, author of The Administrative Process ${ }^{8}$ and at one time, Dean of the Harvard Law School.

Among those attacking the policies of the Commission on different grounds are Honorable Lowell B. Mason, himself a member of the Commission, the Senate Subcommittee on Pricing headed by Senator Homer Capehart of Indiana in the 80th Congress, and Senator Edwin C. Johnson of Colorado in the 81st Congress, and certain somewhat vaguely defined business groups represented by $\mathrm{Mr}$. Simon. There are many more critics in this category than there are among those urging stricter enforcement. Many of those who feel they have been adversely affected by past Commission orders, their attorneys, and their friends in Congress have naturally exhibited some antagonism toward the Commission.

\section{Criticisms of Those Wanting More Enforcement}

The Patman Select Committee on Small Business of the House of Representatives, from whose reports $\mathrm{Mr}$. Simon quotes extensively, sharply criticized the Commission for (1) failure to select its cases more carefully and thus dissipating its energies on matters unimportant to the national economy; ${ }^{9}$ (2) a low level of morale, characterized by internal strife, office politics, indifference toward the work of the agency, and a reluctance to face new issues $;^{10}$ and (3) the time consuming nature of the Commission's procedures. ${ }^{11}$

But the main faults the Patman Committee had to find with the Commission are just the opposite of Mr. Simon's objections to the Commission. The report of this Committee complimented the Commission for its "considerable progress in recent years in identifying discriminatory deliveredpricing systems and in securing their legal condemnation." Then, in the

${ }^{8}$ Landis, The Administrative Process (1938).

${ }^{9}$ H.R. Rep. No. 3236, 81st Cong. 2d Sess. (1951), at 17.

${ }^{10}$ Ibid., at 18.

IIIbid., at 19. 
next passage, it chastised the Commission for "losing some of its earlier enthusiasm" and weakening before the pressures of "special interests" seeking to sell the public on these systems. ${ }^{12}$

The Committee report particularly approved of the Conduit case ${ }^{13}$ on the ground that this kind of law recognizes and circumvents the difficulty of proving "conspiracy" in delivered-price systems and on the ground that it will "enable more effective relief to be secured." $\mathrm{Mr}$. Simon, in contrast, has disapproved most heartily of the rigid Conduit case.

The Committee report urged the Commission on to "challenge the use of any and all discriminatory delivered-price systems used by an industry group which involve any significant degree of phantom freight or freight absorption."15

And finally, speaking of the construction put on the good faith defense by the Circuit Court in the Standard Oil case, ${ }^{16}$ the Committee report said: The rule of law thus established in the Standard Oil of Indiana case is highly signifcant. Vigorous and thoroughgoing application of this rule will do much to deny to large corporations operating in many sales areas or with concentrated financial resources the power to match or undercut local prices to the injury of small business. ${ }^{17}$

The same Committee's reports made it abundantly clear that it favored more effective enforcement. It recommended that while the FTC should make improvements, it should be given strengthened statutory authority and increased operating funds for its unequal battle against monopoly and unfair methods of competition. ${ }^{18}$ Congressman Patman, the chairman of

12 Tbid., at 34 .

13 FTC Doc. No. 4452, 38 F.T.C. 534 (1944), aff'd, Triangle Conduit \& Cable Co. v. FTC, 168 F. 2 d 175 (C.A. 7th, 1948), aff'd by an equally divided court (per curiam), 336 U.S. 956 (1949).

14 The report said: "The rule of law developed in the Conduit case has two principal merits. First, in many situations the task of proving conspiracy has become increasingly difficult as trade members have become more sophisticated and secretive in their agreements. Secondly, it enables more effective relief to be secured. If a cease-and-desist order simply condemns conspiracy in the use of basing-point pricing, it is likely, as the records of compliance show, that the practitioners will continue the formula or some modification thereof and insist that they are acting individually." Op. cit. supra note 9 , at 34.

15 Ibid., at 35.

16 Op. cit. supra note 6.

${ }^{17}$ Op. cit. supra note 9, at 36.

$18 \mathrm{Ibid}$., at 45 . The Committee also refers to the cease and desist order as the major remedial instrument available to the Commission and states:

"No other major regulatory agency is faced with so huge a task as the Commission with such feeble weapons." Ibid., at 29.

The Committee has also said:

"Compared with other regulatory agencies, the arsenal of weapons available to the Commission is woefully meager." H.R. Rep. No. 3237, 81st Cong. 2d Sess. 104 (1951).

In recommending that the Commission be granted additional funds to carry out its statutory duties more satisfactorily, the Committee concludes: 
this Committee, led the floor fight against the bill urged by Mr. Simon to overturn the FTC's action with respect to the basing point system.

In further support of his attack upon the FTC, Mr. Simon cites the Hoover Report. It is true that the Hoover Commission points out that the FTC over the years "has engaged mainly in activities contributing little toward accomplishing the primary congressional objective of assuring widespread effective competition," and has been preoccupied with minor matters, except for the basing point cases. ${ }^{19}$ Yet, the Hoover Commission, like the Patman Committee, made it clear that the remedy for the FTC's shortcomings was neither abolition nor transference to the Department of Justice, but rather a strengthening of its authority and effectiveness. The Commission on Organization of the Executive Branch of the Government (the Hoover Commission itself, not the Task Force) stated in its report that it

believes that the independent regulatory commissions have a proper place in the machinery of our Government, a place very like that originally conceived. ${ }^{20}$

To the same effect is the Task Force conclusion that:

The independent regulatory commission is a useful and desirable agency where constant adaptation to changing conditions and delegation of wide discretion in administration are essential to effective regulation. ${ }^{21}$

And, with particular reference to the FTC, the Report stated:

We have carefully considered whether the Federal Trade Commission should be continued as an independent regulatory commission, and especially whether its functions

\footnotetext{
"The need for larger appropriations to finance our business regulating programs has been repeatedly pointed out. The committee believes that more and better men, and hence more money, are basic to the necessary enhancement of the effectiveness of the antitrust laws. We are convinced that this is true of the Federal Trade Commission as well as of other agencies." H.R. Rep. No. 3236, 81st Cong. 2d Sess. 44 (1951).

To further illustrate its point, the Committee recites these facts:

- "On June 30, 1950, the Federal Trade Commission had only 98 attorneys engaged in enforcing the antimonopoly provisions of the Federal Trade Commission and Clayton Acts. In one case before the Commission at the time this was being written, the respondents were represented by 102 separate law firms. To meet this force of legal talent the Commission had the services of one principal attorney and two part-time assistants. For every dollar spent by the public in defending itself against monopoly the respondents spend thousands. Under the circumstances it is to be expected that only the surface of the problem of unfair competition is being scratched.

"One would expect that the Federal Trade Commission, charged as it is with the duty of maintaining the general plane of competition throughout the American economy, would be treated as liberally as any regulatory agency. As a matter of fact, however, the Federal Trade Commission ranks near the bottom of the list in respect to the size of its appropriations. In 1950 it was exceeded, among others, by the Interstate Commerce Commission, the Federal Communications Commission, the Securities and Exchange Commission, the Food and Drug Administration, and the Federal Power Commission." Ibid.

${ }^{19}$ H.R. Doc. No. 116, 81st Cong. 1st Sess. 122 (App. N., 1949).

${ }^{20}$ The Hoover Commission Report 431 (1949).

${ }^{21}$ H.R. Doc. No. 116, 81st Cong. 1st Sess. viii (App. N., 1949).
} 
in the broad anti-monopoly field should be transferred to the Department of Justice. Our conclusion, as already indicated, is that the Commission should be maintained in order to implement the policy of the anti-trust laws.22

This would hardly indicate any sympathy with Mr. Simon's thesis.

Another criticism of the Commission is found in the Landis dissent from the Report of the Committee on Cartels and Monopoly.23 This report considered the question of any overlapping or duplication between the Department of Justice and the FTC and recommended that there be developed a closer coordination and working together of the two agencies to accomplish their common objectives. It also recommended substantial increases in the appropriations of the Commission to enable it to cope adequately with its statutory duties. ${ }^{24}$

Mr. Landis, dissenting from the majority's recommendation that more appropriations be granted to the Commission, said: "I would agree to a recommendation that would give adequate appropriations and staff to a new Commission." ${ }^{25}$ Mr. Landis' statements indicated a dislike for the

22 Ibid., at 123. The Report stated further:

"By long tradition, this country is committed to the maintenance of the system of competitive enterprise and widespread opportunities for independent businesses. This policy has its roots both in the democratic political tradition of equality of opportunity, and in the belief that economic progress, efficiency, and social stability are promoted by the spur of competition. The antitrust laws are the instrument for achieving this long-range policy. They are based on the recognition that to maintain effective competition requires vigilance in preventing and correcting restrictive or monopolistic practices.

"In part this can be achieved through court actions by the Department of Justice under the Sherman Act. But the Antitrust Division has been essentially a prosecuting agency; its interest has been primarily that of bringing violators into court to secure a conviction or judgment. In this field, particularly in the last 10 years, it has been singularly successful and has performed useful public service.

"Another kind of job in the antitrust field is for the administrative agency. There is need for an economic staff systematically surveying our economy; probing for industrial and economic practices which threaten the elimination of competitive conditions; identifying restrictive tendencies before they become too solidly entrenched; analyzing the basic disorders found and formulating methods for their practical correction. Such a procedure gives the policy of the statutes continuous vitality in terms of current conditions. It also places stress on the basic purpose of the legisiation-the practical correction of trade practices to bring them in conformity with the public interest. These are the basic purposes of the Federal Trade Commission Act.

"These tasks are peculiarly suited to an independent agency. The single forum provides a continuity in approach to the problems and method of handling. The bipartisan commission is relatively immune to the political winds which blow through the executive departments; the Antitrust Division, by contrast, has had to clear some specific cases and general programs with the President. With a permanent economic staff, the Commission has the opportunity for an orderly development of program. The staff can focus more upon economic disorders and their remedies, than on winning cases as is the tendency in a department necessarily dominated by lawyers. If properly organized, an independent agency is superior to the executive departments and the courts in providing continuity in following up decrees, surveying compliance, and evaluating the remedies." Ibid., at 124.

- ${ }^{23}$ Appearing as Chapter 16 of Stocking and Watkins, Monopoly and Free Enterprise (1951).
24 Ibid., at 565.
${ }^{25}$ Ibid. 
present Commission. ${ }^{26}$ However, he has made it clear that he favors the use of the administrative process in the handling of antitrust matters, and hence that he would not agree with Mr. Simon's proposal for a transfer of the FTC to the Department of Justice. ${ }^{27}$

\section{Critics Favoring Less Enforcement}

Statements of FTC Commissioner Mason are also cited by Mr. Simon. Commissioner Mason is known as a vigorous critic of the antitrust laws, and of both the Commission and the Department of Justice. On occasion he has asserted that we should relegate our antitrust laws to the Smithsonian Institution, and with apparent seriousness, has urged that the Commission be empowered to operate as a kind of super NRA, working out trade practice rules in cooperation with business groups under terms which would give signatories to such rules immunity from the antitrust laws. ${ }^{28}$ Commissioner Mason's recommendations warrant close scrutiny. The candor of his criticisms appears to flow from an understanding of the extent to which the antitrust laws have failed. The nature of his recommendations, however, places them outside the scope of the issues here under discussion.

The Senate Subcommittee on Pricing has also been extremely critical of the FTC, and Mr. Simon has quoted extensively from their reports. ${ }^{29}$

\section{The Laws under Attack}

Another preliminary step, after setting forth the cast of characters, is to make clear which laws are under attack. There are two laws under specific attack: Section 5 of the Federal Trade Commission Act; ${ }^{30}$ and Section 2 of the Clayton Act, as amended by the Robinson-Patman Act. ${ }^{31}$ Section 5 of the Federal Trade Commission Act declares unlawful "unfair methods of competition in commerce." Other sections of this Act authorize the FTC to issue cease and desist orders against "unfair methods of competition" and set out the procedures to be followed. Section 2 of the Clayton

26 Ibid., at 548.

${ }^{27}$ Landis, op. cit. supra note 8 , at 32-33, and 35.

${ }^{28}$ See Mason, Let's Stop Kicking Business Around, American Magazine, at 21, 136-37 (May, 1948). See also mimeographed Address to the Joint Meeting of the American and Chicago Bar Ass'n Committee on Federal Law, Chicago. (October 13, 1947).

${ }^{29}$ Simon, op. cit. supra note 2, at 297. Mr. Simon was General Counsel of the Subcommittee and in large part managed the hearings and prepared the reports of that Subcommittee and therefore was often quoting himself in his article for the University of Chicago Law Review. For a critical discussion see Latham, The Politics of Basing Point Legislation, $15 \mathrm{Law} \&$ Contemp. Prob. 273 (1950).

3038 Stat. 717 (1914), 15 U.S.C.A. $\$ 45$ (1951).

3149 Stat. 1520 (1936), as amended, 15 U.S.C.A. $\$ 13$ (1951). 
Act, as amended by the Robinson-Patman Act, forbids certain price discriminations. The FTC has no jurisdiction whatever over the Sherman Act.

The business practices which these laws have embarrassed are: (1) price fixing by the basing point method, and (2) price discrimination used to create or maintain a quasi-monopoly position. The former is a multilateral understanding to maintain prices; the latter is a unilateral use of power to administer prices and to forestall market inroads by smaller competitors. Wherever we find that competition is lacking in an industry we usually find that one or the other of these conditions prevails.

\section{Price Fixing by the Basing Point System}

The Supreme Court in FTC v. Cement Institute S2 $^{32}$ held the basing point system to be in violation of Section 5 of the Federal Trade Commission Act, where the system was found to be practiced by conspiracy or agreement among competitors. Moreover, the Court has held on several occasions that particular basing point systems were violative of Section 2 of the Clayton Act, as amended. ${ }^{33}$ Such holdings have been on the ground that the system involves discriminations in price between buyers at different locations and the effect has been either (a) to injure buyers at some locations, to the advantage of buyers at other locations, or (b) to suppress price competition among sellers.

It is, moreover, established law that a discrimination in price on the part of an individual firm is, under certain circumstances, also violative of Section 2 of the Clayton Act, as amended. In general, the circumstances are: (a) "where the effect of such discrimination may be substantially to lessen competition," and (b) where the discrimination is not justified by differences in the seller's costs of supplying the different buyers. In short, the law is not intended to prevent discriminations which have no substantial effect upon competition; and the statute expressly permits any savings generated by a particular buyer's business to be passed on to that buyer. ${ }^{34}$

32 Op. cit. supra note 7.

${ }^{33}$ Corn Products Refining Co., FTC Doc. No. 3633, 34 F.T.C. 850 (1942), aff'd, Corn Products Refining Co. v. FTC, 144 F. 2d 211 (C.A. 7th, 1944), aff'd, 324 U.S. 726 (1945); Staley Mfg. Co., FTC Doc. No. 3803, 34 F.T.C. 1362 (1942), rev'd, Staley Mfg. Co. v. FTC, 144 F. 2d 221 (C.A. 7th, 1944), rev'd, 324 U.S. 746 (1945).

${ }^{34}$ Section 2(a) of the amended Clayton Act, however, provides that the Commission "may, after due investigation and hearing to all interested parties, fix and establish quantity limits, and revise the same as it finds necessary, as to particular commodities or classes of commodities, where it finds that available purchasers in greater quantities are so few as to render differentials on account thereof unjustly discriminatory or promotive of monopoly in any line of commerce." 38 Stat. 730 (1914), as amended, 49 Stat. 1526 (1936), 15 U.S.C.A. § 13(a) (1951). This provision was not used until December 13,1951, when the Commission issued its findings 


\section{Price Discriminations-Not the Same as "Price Cuts"}

In discussing price discrimination, it is important to keep in mind that a "price cut" is not necessarily a "price discrimination." A price cut may be made to all buyers; a price discrimination is the practice of selling simultaneously, at different prices, to different classes of buyers. Simple as this distinction may appear, the failure to observe it has tricked many people, including a few federal courts. The practice in some quarters of referring to some price discrimination as "good faith competition" has not improved matters.

The Clayton Act, as amended, does not prohibit price cuts which are made available to all buyers, whether such cuts are made in "good faith" or "bad faith." On the contrary, the purpose of the law is to encourage general price cuts, and to assure smaller business firms an individual freedom to make price cuts. Price discrimination discourages general price cuts for two reasons. First, a price discrimination is an abuse of power by which large sellers eliminate their smaller competitors, and its long-term effect is to concentrate business by bludgeoning methods. Second, it is an abuse of power by which large sellers discourage small sellers from reducing prices. To effectuate this discouragement it is only necessary for the large seller to single out the customers to whom the smaller competitor offers price cuts and either "meet" or "beat" the offer. Of course, if the price administrator were required to "meet" or "beat" uniformly, so that all of his customers are accorded the lower price, the prospect might not be so tempting. In fact, both large and small sellers would be on an equal footing, with the question of which is to win out placed squarely on the question of efficiency. It is through the use of price discrimination that superior financial power comes to be an important determining factor in the competitive contest.

It has long been established that discriminations in price to "undercut" the price of a competitor are illegal, where the other circumstances making for illegality are present. Such discriminations are, moreover, generally and correctly regarded as damaging to the business system. On the other hand there is considerable misunderstanding of the effects of discrimination which merely "meet" the prices of a competitor. Such discriminations are frequently thought to be harmless, or perhaps even to stimulate more vigorous competition. There is no doubt that in many marketing situations they are harmless; but to conclude that all discriminatory meetings

and order fixing 20,000 pounds ordered for delivery at one time as the limit up to which price differences based on quantity would be permitted in the sale of replacement rubber tires and tubes for motor vehicles. 
of prices are harmless is to overlook the advantages which big sellers have over small sellers in this situation.

Much support has recently been given to the contrary point of view by the Supreme Court's decision in Standard Oil (Indiana) Company v. FTC. ${ }^{35}$ In this case the Court decided that the Robinson-Patman amendment to the Clayton Act had not, contrary to the belief of some of its sponsors, overturned "good faith" as an absolute defense to a charge of practicing harmful price discrimination. The discriminatory meeting of competitors' prices now has clear sailing, no matter what the effects-with one qualification: the discrimination must be "made in good faith to meet an equally low price of a competitor."

In view of the economic issues involved, it should now be apparent which business groups have been offended by the two laws which are under attack. One other group must be added to the list: where sellers engage in price discrimination, it frequently happens that the bigger buyers receive the lower prices and the smaller buyers are charged the higher prices. Consequently, there are some large buyers who have grown accustomed to such advantages over their smaller competitors and would naturally like to keep matters this way. It is not surprising, therefore, that there should be lobbyists at work with great sums of money at their disposal for wrecking these two laws by one means or another.

\section{Attack on the Purpose of the FTC}

During the past four years Congress has spent a great deal of time considering and debating various of Mr. Simon's proposals for changing the two laws which have given offense. Several bills to amend these laws have been introduced.$^{36}$ One of them actually passed, and failed to become law only by Presidential veto. ${ }^{37}$ Moreover, the last of the series passed the Senate, by a narrow margin, during the last session..$^{38}$ But to all appearances this one has bogged down in the House, since open hearings before the Celler Committee have brought out some features which were perhaps overlooked in the Senate.

When Congress drafted the Federal Trade Commission Act in 1914, it was after a long demonstration of the inability of the federal courts to cope with the complexities of antitrust problems. Consequently, the legislation

${ }^{25}$ FTC Doc. No. 4389, 41 F.T.C. 263 (1945), modified, 43 F.T.C. 56 (1946), aff'd, 173 F. $2 d$ 210 (C.A. 7th, 1949), rev'd, 340 U.S. 231 (1951).

${ }^{36}$ Sen. 236, 81st Cong. 1st Sess. (1949); H.R. 1427, 81st Cong. 1st Sess. (1949); Sen. 1008, 81st Cong. 1st Sess. (1949); H.R. 2222, 81st Cong. 1st Sess. (1949); H.R. 4669, 81st Cong. 1st Sess. (1949); Sen. 719, 82d Cong. 1st Sess. (1951); H.R. 2820, 82d Cong. 1st Sess. (1951).

${ }^{37}$ Sen. 1008, 81st Cong. 2d Sess. (1950).

${ }^{38}$ Sen. 719, 82d Cong. 1st Sess. (1951). Approved by Senate on August 2, 1951, after limited debate, by a vote of 42 to 34 . 
establishing the Commission provided for a body to make findings of fact. The Commission's actions are subject to review by the higher courts, and, in addition to the procedures which are prescribed in the Federal Trade Commission Act, the Commission's findings are subject to the Administrative Procedure Act. ${ }^{39}$ The Commission's findings must be based upon "reliable, substantial and probative evidence," and the courts may upset its findings if they are not so grounded. But the appellate courts cannot reverse the Commission's findings of fact, in theory at least, merely because the court would reach a different conclusion on the "weight" of the evidence.

Mr. Simon's latest proposals can be fully appreciated only in relation to this phase of the history of the FTC Act. At the moment, he seems to have failed in his efforts to pass any of his proposals to make direct amendments to the laws he finds offensive, although he appears to have succeeded in persuading the Supreme Court, temporarily at least, that price discrimination results in wholesome competition. Perhaps many of those involved in antitrust litigation feel that they would stand a better chance of escaping the antitrust laws if the federal courts, rather than the Commission, were to make findings of fact on such questions as whether there is conspiracy, whether there is "good faith" abuse of power, and whether the effects of a particular discriminatory practice substantially lessen competition. In this respect they are probably right. It was just such considerations that prompted the creation of the Commission in the first place.

Origins of the Attack ,

The decision in FTC v. Cement Irstitute was handed down on April 26, $1948 .^{40}$ In a six-to-one decision the Supreme Court upheld the Commission's findings that the cement industry had agreed and conspired to fix prices and eliminate competition through use of a multiple basing point system. The Court also upheld the Commission's cease and desist order.

The next day Mr. Irvin S. Olds, Chairman of the Board of United States Steel Corporation, held a press conference which was reported in the New York Journal of Commerce of the following day under the following headlines:

MOVE FOR CONGRESS ACTION RUSHED TO AVERT DISRUPTIVE IMPACT OF BAN ON BASING POINTS IN NATION'S INDUSTRY-OLDS ASSERTS PROMPT LEGISLATION ESSENTIAL: SEES ALL LINES HIT ${ }^{41}$

${ }^{39} 60$ Stat. 237 (1946), as amended, 5 U.S.C.A. $\$ 1001$ (Supp., 1950).

${ }^{40}$ FTC Doc. No. 3167,37 F.T.C. 87 (1943), rev'd, 157 F. 2d 533 (C.A. 7th, 1946), rev'd, 333 U.S. 683 (1948).

4N.Y. J. of Comm., p. 1, cols. 6-8 (April 28, 1948). 
In this news story $\mathrm{Mr}$. Olds was credited with a view of the decision that became the first theme song of a campaign which, though it has subsequently had other theme songs, has been waged continuously since that day. This theme was that industry would have to be extensively relocated. ${ }^{42}$ The same article credited Mr. Olds with the statement that "industry was faced with two alternatives-either to seek remedial legislation, or to 'educate the Supreme Court." "43

In the weeks immediately following the Cement decision a few of the trade journals took up the cry of alarm. Industrial plants were about to relocate, according to these journals, and various specified and unspecified industrial centers were about to become "ghost towns." Several lobbies were organized, not only to petition members of Congress, but to send missionaries out to the hinterlands and organize so-called "grass roots" lobbies. ${ }^{44}$ On June 10, 1948, the Senate passed a resolution offered by Senator Capehart to investigate the effects of recent court decisions and FTC pricing policies. ${ }^{45}$ The Capehart investigating subcommittee was organized and appointed a "business advisory council" composed of several scores of businessmen, many of whom were from basing point industries or other firms having recent difficulties with the antitrust laws.

\section{The Adoption of F.O.B. Pricing by Steel}

The real pressures did not develop, however, until midsummer of 1948. On July 8 of that year the United States Steel Corporation dropped its basing point system and changed to an f.o.b. mill pricing, announcing that it was required to do so by the Cement decision. ${ }^{46}$ Other members of the steel industry followed suit. The steel industry's adoption of f.o.b. mill pricing in July accomplished two results. First, this was an indirect means of raising prices. Under the basing point system each mill had absorbed freight on shipments into another mill's territory; now each mill charged the customers full freight costs. In the second place, this move put a "squeeze" on many steel customers. For example, a fabricator in Chicago who had been buying his steel from Pittsburgh now had to pay a substantially higher delivered cost for his raw materials than a neighboring competitor who happened to have bought his steel from a Chicago mill.

12 Tbid., at col. 8.

43 Ibid.

${ }^{4}$ Speech of Senator Wayne Morse, 95 Cong. Rec. 7025-26 (1949).

4594 Cong. Rec. 7949 (1948).

* In N.Y. J. of Comm., p. 1, col. 6 (July 8, 1948), Benjamin Fairless, President of U.S. Steel, is reported as stating that "the move results from the recent decision of the Supreme Court in Federal Trade Commission proceedings against the cement industry," and that "we have no other recourse than to comply with the law of the land as determined by the Supreme Court." 
Similarly, this fabricator's counterpart in Pittsburgh, having previously bought his steel from a Chicago mill, was at a disadvantage with his neighboring competitors who bought from Pittsburgh mills. Of course both the Chicago and Pittsburgh steel customers would have been glad to exchange suppliers; but this was not possible because of the steel industry's shortage policy which required each mill to reject new customers and supply only its old customers.

If matters were not complicated enough, steel executives wrote letters to customers throughout the country, blaming the whole matter on the FTC and hinting at more dire consequences yet to come. Steel salesmen suggested to customers, who were then desperately anxious to obtain steel, that Congress be asked to legalize basing point practices. ${ }^{47}$

\section{"Confusion"}

All things considered, there was much genuine confusion. On the one hand several members of Congress were pointing out that the Supreme Court's decision in the Cement case had specifically said that independent freight absorption was not prohibited. ${ }^{48}$ On the other hand, the business community had statements to the contrary from no less a business authority than the United States Steel Corporation, plus a practical demonstration indicating that the steel industry itself thought f.o.b. mill the only legal method of pricing. "Confusion" then became the new campaign slogan, and it was exploited to the fullest. ${ }^{49}$

${ }^{47}$ Latham, The Politics of Basing Point Legislation, 15 Law \& Contemp. Prob. 272, $275 \mathrm{n}$. 19 (1950).

${ }^{48}$ The Supreme Court had said:

"Most of the objections to the order appear to rest on the premise that its terms will bar an individual cement producer from selling cement at delivered prices such that its net return from one customer will be less than from another, even if the particular sale be made in good faith to meet the lower price of a competitor. The Commission disclaims that the order can possibly be so understood. Nor do we so understand it." FTC v. Cement Inst., 333 U.S. 683, 727 (1948).

49 The following quotation taken from Business Week is fairly typical of how this confusion was propagated:

"All was confusion on the delivered-pricing front this week. Only two things were sure: Everyone concerned will be happy when Senator Capehart's investigating committee starts its hearings; everybody will be even happier when, and if, the committee finally comes up with legislation to clear up the uncertainties that now prevail." Prices: Confused, Business Week at 20 (Sept. 25, 1948).

Another way to illustrate very easily the theme of the basing point defenders is to quote the titles of various articles which indicate the then prevailing campaign of confusion: Simon, Economic Chaos Threatened by Bureaucratic-Made Confusion in Pricing, 99 Automotive Industries, No. 12, at 24 (Dec. 15, 1948); Burns, If You're in Business You're Probably Guilty, 28 Barrons, No. 44, at 5 (Nov. 1, 1948); Steel Price Maze Unwinding, Business Week at 25 (July 17, 1948); Prices: Confused, Business Week at 20 (Sept. 25, 1948); FTC Stand on Pricing Systems, Business Week at 23 (Oct. 23, 1948); Clarification of Pricing System Urged, Concrete at 30 (Nov. 1948); Basing Points: The Great Muddle, 38 Fortune, No. 3, at 73 (Sept. 1948); Simon, Objective of Capehart Committee To Clarify Confusion on 
A year and a half later, it occurred to one of the authors (then the junior Senator from Illinois) that Congress should have the facts as to how the cement companies had, in practice, interpreted the Cement order with respect to the legality of independent freight absorption, and he wrote to the Commission seeking enlightenment. The Commission replied that each company receiving a cease and desist order is required to file a formal report setting out the ways in which it has modified its practices in response to a Commission order, and that such reports had been filed by the cement companies in September, $1948 .^{50}$ The Commission further reported that fifty-five cement companies, operating 152 plants, were bound by the cement order. Of these, thirty-seven cement companies operating 113 plants filed reports stating definitely their intention of absorbing freight, and only three companies indicated that they interpreted the order as having the practical effect of preventing them from absorbing freight. The other companies either neglected to indicate that the question created any problem, or described their intended practices in such a way that it is impossible to tell definitely whether their practices would involve freight absorption. ${ }^{5 x}$

The Commission also provided excerpts from the company reports, including an excerpt from the report of the Universal Atlas Cement Company, a subsidiary of U.S. Steel, which clearly stated that the company interpreted the Cement order as permitting independent freight absorption. ${ }^{52}$ Here, obviously, was an instance where the Corporation's lawyers had gotten their tactical wires crossed. U.S. Steel had told the public through the press, in July, ${ }^{53}$ that the Cement order required it to price steel f.o.b. mill, yet its subsidiary cement corporation formally reported to the Commission in September that it understood the order to permit freight absorption on cement. But this all came out later.

As a result of the confusion created in midsummer of 1948, a number of the members of Congress were persuaded that new legislation was needed to clarify matters. Some of these recognized that the confusion had been

Pricing, 161 Iron Age, No. 19, at 128 (May 6, 1948); Sullivan, Chaos Seen if Multiple Basing Point Sales System Is Outlawed, 161 Iron Age, No. 19, at 123 (May 6, 1948); Day, Pricing Systems, Which Ones Are Legal?, Nat'l Petroleum News at 46 (Jan. 26, 1949); Pricing Muddle, FTC and Supreme Court Price Decisions, Newsweek at 70 (Dec. 13, 1948).

We are indebted for the citations in this note to Howard Ralph Horrow. Horrow, Business Reactions to Court Decisions Against Basing Point Pricing Methods (Thesis, University of Illinois, 1951).

${ }^{50}$ Letter from Commissioner Lowell B. Mason to Senator Paul H. Douglas, March 20, 1950, appearing in 96 Cong. Rec. 7866 (1950).

51 Ibid. 52 Tbid.

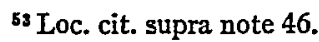


artificially manufactured, but felt that it should be dispelled no matter what its origins. A number of bills aimed at clarification were introduced. Unfortunately, while some of these might have clarified the antitrust laws, any one of them would have seriously weakened these laws.

\section{The Basing Point System ${ }^{54}$}

To work successfully, the basing point system requires that industry members cooperate in a number of ways to maintain uniform business practices. But primarily, the system is a formula used for determining what delivered price is to be quoted to any prospective buyer. The basing point formula itself is composed of two parts. These two parts, when added together, make the delivered price which is charged buyers at any particular location in the country. The first part is a base price which is announced at some place designated as a "basing point." The second part of the formula is the established freight charge for shipping the goods from the basing point to the buyer's location. Adding these two parts of the formula together, all producers in the basing point system arrive at the same delivered price for any particular buyer. All producers charge the buyer the same base price, plus the same established freight charge, regardless of the actual point of origin of the goods or the freight charges actually incurred. Thus, the basing point system is a foolproof method of destroying price competition. And where all producers of an industry have standardized their products, their services, and their terms of sale, price competition is the only kind of competition that matters.

\section{The Origin of the Basing Point System}

The basing point system made its first appearance in the United States in 1880 when the Carnegie Steel Company joined with three other firms in Pennsylvania and New Jersey and formed the Pittsburgh Steel Beam Association for the purpose of fixing the delivered price of steel beams. The price plan agreed upon inaugurated the "Pittsburgh plus" formula ${ }^{55}$ which was quite simple. The four members of the association agreed upon a common base price at Pittsburgh and agreed to make all sales from their variously located plants at the Pittsburgh price, plus ithe established rail freight charges from Pittsburgh to the buyer's location. In this way they could all quote the same delivered price to any prospective buyer. This system was to become, some twenty or thirty years later, the "Pittsburgh

${ }^{54}$ For a fuller analysis of the basing point system, see Machlup, The Basing Point System (1949). See also Douglas Speech, 96 Cong. Rec. 7851-69 (1950), and Mund, The Development and Incidence of Delivered Pricing in American Industry, 15 Law \& Contemp. Prob. 141 (1950).

${ }^{55}$ FTC v. U.S. Steel Corp., FTC Doc. No. 760, 2 Statement of Case 638-39 (1924), cited by Mund, op. cit. supra note 54, at 143 n. 4. 
plus" system by which the prices of all steel products were fixed over the entire United States. Its use with variations was eventually adopted by other industries such as cement and corn syrup.

After the formation of the United States Steel Corporation in 1901, the Corporation began to set the delivered prices for all its mills outside of Pittsburgh to include the Pittsburgh base price, plus the rail freight from Pittsburgh to the buyer's destination. Other steel companies, fearing reprisals at the hands of the giant U.S. Steel combine if they refused to go along, agreed to do likewise. This formula was extended to one line of steel products after another as rapidly as agreements could be reached. Simple as this formula may seem to us now, it still was a novel idea to many of the steel companies in 1901 despite its earlier practical demonstration in selected fields. For example, consider a report covering the agreement worked out in 1901 for bars and plates:

Early in the year it looked as though there might be a somewhat demoralized market for bars and plates, but this was fortunately avoided by the manufacturers of each of these specialties formulating plans for maintaining uniform prices, which have proved to be eminently successful. It took a good deal of time to arrive at a basis which would be satisfactory to all the various interests, one great diffculty being in the variety of conditions in regard to location of mill, proximity to markets, cost of production, etc. The plan finally adopted and which has worked perfectly so far, and which is likely to be continued indefinitely, was to base all quotations at a figure agreed upon for f.o.b. deliveries in Pittsburgh. The local mills (Philadelphia) therefore quote Pittsburg prices-plus freight to whatever point the material has to be shipped.... The plate mills have a verbal agreement and the bar mills have a written agreement which is further strengthened by a substantial cash deposit. The lowest prices during the year were $\$ 1.35$ for bars and $\$ 1.40$ for plates, but under the price agreement they are now $\$ 1.62$ and $\$ 1.72$, and likely to remain at that for an indefinite period. ${ }^{\text {.s }}$

\section{Principles of Multiple Basing Point System Same as "Pittsburgh Plus"}

The principles of the multiple basing point system are the same as the single basing point, or "Pittsburgh plus" system. The only difference is that, instead of having only one basing point, the multiple system has two or more basing points. It is carried on in exactly the same manner as "Pittsburgh plus," except that all mills charge any customer the established price at the basing point nearest that customer plus the rail freight from that basing point. Like "Pittsburgh plus," it results in the elimination of price competition, since the buyer is still confronted with identical price quotations from all sellers who call to supply him.

When the FTC ordered U.S. Steel to stop using the "Pittsburgh plus" system in 1925, the Corporation agreed "insofar as it is practicable to do

${ }^{50}$ Philadelphia Iron Market for 1901, Annual Rev. of N.Y. Metal Exchange at 3 (1902), cited by Mund, op. cit. supra note 54, at 147 n. 15. 
so." ${ }^{\prime 57}$ What the Corporation actually did was to adopt several other cities as basing points. In other words, the steel industry merely shifted from the single to the multiple system. This was the system then employed by the cement industry.

\section{Bad Results of Basing Point System Summarized}

The bad results of the basing point system may be summarized as follows:

1. Price Discrimination. Under the basing point system the seller pays all of the freight charges for some buyers, pays part of the freight charges for other buyers, and then charges phantom freight to still other buyers. When the amounts of such discriminations are large, the practice injures some fabricators who depend on the basing point industries for raw materials, while it gives undue advantages to other such fabricators.

2. Wasteful Use of Transportation Facilities. The system results in wasteful use of transportation facilities in two ways. First, it results in wasteful cross-hauling. Since the buyer is offered identical delivered prices by all mills, both near and far, he frequently buys from a distant mill, while buyers in the home town of that distant mill are themselves going abroad for identical materials.

The second way in which the basing point system results in wasteful use of transportation facilities is in causing shipments to be made by rail, even where cheaper means of transportation, such as barges or trucks, are available. In order to quote identical delivered prices, the basing point industry must use a basing point formula which recognizes one and only one set of freight charges. Rail freight charges are the most stable, and consequently they are usually adopted for this purpose. The result is that, since buyers have to pay rail charges anyway - no matter how the goods are shippedthey usually expect to have their goods delivered by the transportation service for which they are paying. Therefore, the mills usually ship by rail in order to avoid incidental protests which might threaten their whole basing point system.

3. Big Company Management of Prices. The basing point system allows a few big companies to control the prices of many small companies. A large company can, by selling a small fraction of its total output at dumping prices, drive the price down in the entire territory of small isolated mills. Small mills cannot do the same to drive the price down in the territory of large mills. The result is that the small producer, located away from the principal market centers, cannot reduce prices in his local markets, even when he wishes to do so. He knows that as a minimum the big

${ }^{57}$ Report of Compliance, FTC Doc. No. 760. 
mills will dump to meet any price reduction he may make, and they may even set a lower price in his area and drive him out of business. Of course some small producers may enjoy coming under the price umbrella of the basing point system so that they need not worry about the necessity of competing. But they cannot increase their share of the market by reducing prices, so they cannot grow. Should some ambitious small producer try it, he would find it difficult, if not impossible, to get the necessary financial backing to carry on a price war with the powerful industry leaders.

4. Undue Centralization of Industry. Since the basing point system makes it unprofitable, if not commercially impossible, for small mills in many scattered places of the country to reduce prices, the result is that mills tend to concentrate in the areas of the big production centers. The basing point system also keeps down the level of new investment in a general way, because monopoly control always means higher prices, lower production, lower employment than would be the case under competition and, consequently, a restricted opportunity for expansion.

\section{Weight of Evidence in Basing Point Conspiracies}

It appears that when the basing point system was a new phenomenon in American industry, industry meetings, explanations, assurances, reassurances and even "cash deposits" were needed to insure uniform observance. ${ }^{58}$ Today such overt acts of conspiracy would hardly be considered necessary. Where, therefore, is there to be found the old-fashioned detective-type evidence which the federal courts usually require for finding conspiracy? The clean-cut lads of the FBI deserve the respect and admiration of the country. But when they are sent out by the Department of Justice to find evidence of a price-fixing conspiracy, they are likely to return empty handed. The reason is that their innocent routine is to search business files for evidence which is usually not there. Even if the evidence had once been there, counsel would almost surely have made management aware of its risky significance.

Now let us consider Mr. Simon's public-spirited distaste for "conspiracies." He has said at one place in his article that "[a]t the start we remove all conspiratorial price fixing from consideration for no one supports conspiracies; every one agrees they are wrong." Commission with: "The point is that the Commission's twenty-five year basing point campaign, having now been disowned, was a waste of time which could better have been spent fighting conspiratorial and other predatory practices." 60

ss Op. cit. supra note 56.

so Simon, op. cit. supra note 2 , at 320.

${ }^{60}$ Ibid., at 307 . 
Consider, then, an instance of basing point pricing. In January, 1947, the Illinois Department of Highways had asked for bids on some 50,000 barrels of cement delivered inside each of the 102 counties in the State. In response to this invitation, eight firms submitted sealed bids, and each of the eight firms bid exactly the same figure for cement to be delivered in each of the 102 counties. The prices bid varied from county to county but in each of the 102 counties the eight firms had all bid alike. ${ }^{61}$ Professor C. O. Oakley of the Department of Mathematics of Haverford College analyzed this record and stated what the chance would be that such identity of eight bids in each of the 102 counties could come about purely by chance. Professor Oakley said that this chance was about one in eight followed by 214 zeros, or less of a chance than the possibility of picking out at random a single predetermined electron in the total universe. ${ }^{62}$ Should such price identity as this then be given any weight as evidence of conspiracy?

Consider then the pending basing point bill, Sen. 719, which Mr. Simon has urged Congress to pass. ${ }^{63}$ Perhaps the best explanation of what is intended by the bill is that given in the report accompanying the bill where it is explained that the record of identical price bids is "admissible as evidence," but that no "adverse inference" may be drawn from such evidence. Nor is any adverse inference to be drawn from the "period of time," the "rigidity," the "frequency" or the "regularity" with which sellers have sold at identical prices. ${ }^{64}$ There appears to be some inconsistency in the position of those who profess concern that "conspiracies" are being neglected, yet would have the things men do by conspiracy given no weight as evidence of conspiracy.

01 Patman, Remarks, 95 Cong. Rec. A3519 (1949).

${ }^{62}$ Letter from Prof. C. O. Oakley to Senator Paul H. Douglas, July 20, 1949, 95 Cong. Rec. 11403 (1949).

${ }^{63}$ The senior Senator from Illinois (Douglas) testified on Sen. 719, 82d Cong. 1st Sess. (1951), during the course of hearings held by the Senate Select Committee on Small Business. The writers understood that while Mr. Simon himself did not testify in support of the bill, he was allotted the time of this committee for witnesses appearing in support of the bill. The Council for Clarification of Pricing Practices with which Simon was connected listed the passage of Sen. 719 as one of its objectives. 97 Cong. Rec. A7308 (1951).

os Sen. Rep. No. 293, 82d Cong. 1st Sess. 6 (1951). The report stated: "The period of time during which, and the rigidity with which, sellers have sold at like prices also is admissible evidence under a charge of conspiracy. Here again such evidence alone does not prove, and no adverse inference may be drawn, from the frequency or regularity with which a seller meets or offers to meet his competitor's lower prices. Where sellers are in fact engaged in price competition, there is no limitation upon the frequency or regularity with which they may meet the equally low price of a competitor, absent any agreement or understanding tending to conspiracy. This is particularly true with regard to freight absorption so as to permit sellers to compete, in distant markets, with more favorably located competitors." 
IV. "Good Faith" Abuse of Power

The Standard Oil (Indiana) ${ }^{65}$ case has defined and, in part, settled the legal issues of price discrimination. The facts of record also affect economic issues. The case involved Standard's discrimination in the price of gasoline sold to buyers in the Detroit area. Certain interpretations of the Commission's position in this case have been publicized to the effect that: (1) the Commission is attempting to force manufacturers and distributors to adopt resale price maintenance, and is thus seeking to restrain competition, and (2) the Commission is attempting to eliminate functional discounts and thus eliminate wholesalers and distributors from the business system. Mr. Simon alternatively imputes both objectives to the Commission. The first of these alleged objectives is used, moreover, as the basis for his claim that the "economic philosophies" of the FTC and the Department of Justice are at odds-that the Commission is trying to force business firms to do things which the Department of Justice would prosecute them for doing.

Actually, the Commission has been consistently unfriendly to the Miller-Tydings Act, ${ }^{66}$ which provides a legal way of maintaining resale prices, and coincidentally, a quite well-known Act which Mr. Simon's article overlooks. The Commission's record also shows that it has been consistently unfriendly to methods of maintaining resale prices not sanctioned by the Miller-Tydings Act.

As for the argument that the Standard Oil (Indiana) case was an attack upon functional discounts, the majority opinion of the Supreme Court held that the fact that the customers receiving the lower prices served some distribution functions was irrelevant to the problem and that the outcome of the case would be the same whether they were regarded as "wholesalers" or "retailers."

What is the problem then? Obviously the answer is not quite so simple as Mr. Simon has put it, namely, that for some reason which is not explained, the Commission is trying to eliminate competition.

${ }^{85}$ Op. cit. supra note 6.

6s 50 Stat. 673 (1937), 15 U.S.C.A. $\$ 1$ (Supp., 1951). The FTC has consistently voiced its opposition to efforts to legalize resale price maintenance. Reference is made to the following Commission reports: Resale Price Maintenance, H.R. Doc. No. 1480, 65th Cong. 2d Sess. 1 (1918); Report on Resale Price Maintenance, H.R. Doc. No. 145, 66th Cong. 1st Sess. 1 (1919); H.R. Doc. No. 546, Parts I and II, 70th Cong. 2d Sess. (1929 and 1931); Legislation of Contracts for Minimum Resale Prices, Sen. Misc. Doc. No. 58, 75th Cong. 1st Sess. 1 (1937); FTC, Report on Resale Price Maintenance (1945).

In hearings before the Subcommittee of the House Judiciary Committee (Feb. 14, 1952) and the House Interstate and Foreign Commerce Commission (Feb. 15, 1952) on pending minimum resale price maintenance bills, Assistant General Counsel James W. Cassedy, speaking for the Commission, voiced the Commission's continuing opposition to such legislation. 
Standard Oil (Indiana) is a very large corporation. It markets gasoline under its trade name in some fourteen states, mostly in the Middle West. Its gasoline marketed in the Detroit area comes from its refinery at Whiting, Indiana, whence it is shipped by tanker to storage tanks outside Detroit, and from there it is distributed to the trade.

Standard supplied, according to the Commission's findings, some 358 retail service stations in the Detroit area. Of these, Standard owned some 200 and leased them to operators, and it leased and subleased 8 others. The remaining 150 were independent operators who owned or leased their stations from someone else. While none of these dealers was bound by any specific contract to deal exclusively in gasoline furnished by Standard, none of them was, in practice, free to shift from one supplier to another. Standard sold to all of them at a uniform "tank wagon" price.

In addition, however, Standard sold to four dealers whom it called "jobbers." These four were more substantial business firms than the ordinary retail dealer, and they had one characteristic which is particularly pertinent to the problem: They had facilities which would have permitted them to handle the gasoline of smaller refiners who had no local storage and distribution facilities of their own. ${ }^{67}$

Standard sold to the four "jobbers" at $1 \frac{1}{2}$ cents a gallon less than the tank wagon price. One of these "jobbers," Citrin-Kolb, in addition to supplying its own retail stations, sold substantial gallonage to another company, which also ran a chain of retail stations, at $1 \frac{1}{2}$ cents less than the tank wagon price. Citrin-Kolb issued special service cards which entitled the holder to a discount of 2 cents a gallon at its retail stations.

A second of the four "jobbers," Ned's, sold at retail exclusively. Ned's retail price was 2 cents below the prevailing retail price at Standard stations. The margin of Standard's retail dealers at the time was 3.3 cents a gallon. There was no evidence that the other two "jobbers" ever caused any price cutting; consequently they can be eliminated from the discussion.

The Commission found that the competitive advantage enjoyed by Ned's and Citrin-Kolb was capable of being used, and had been used, to divert large amounts of business from other gasoline retailers. And it further found that the effect of Standard's discriminations not only "may" be

${ }^{67} \mathrm{Mr}$. Justice Burton described them as follows: "The distinctive characteristics of these 'jobbers' are that each (1) maintains sufficient bulk storage to take delivery of gasoline in tank-car quantities (of 8,000 to 12,000 gallons) rather than in tank-wagon quantities (of 700 to 800 gallons) as is customary for service stations; (2) owns and operates tank wagons and other facilities for delivery of gasoline to service stations; (3) has an established business suffcient to insure purchases of from one to two million gallons a year; and (4) has adequate credit responsibility." Standard Oil Co. v. FTC, 340 U.S. 231, 235-36 (1951). 
substantially to injure competition, but that they had, in fact, substantially injured competition. The Commission had charged Standard with violating Section 2 (a) of the Clayton Act, as amended. ${ }^{68}$ Standard's attempted defenses included: (1) a claim that its discriminations were justified by differences in the cost of supplying the different customers, as provided by Subsection 2 (a) of the Act, and (2) that its discriminations were "made in good faith to meet an equally low price of a competitor," as set out in Subsection 2 (b) of the Act.

Standard attempted, but failed, to show a cost defense; and its subsequent appeal to the Circuit Court omitted this plea. As for the claim that the discriminations were made in "good faith," the Commission made no finding, but "assumed" that there was good faith. The Commission took the position, however, that since it had already fulfilled the burden of showing the discriminations to have, in fact, the effect of substantially injuring competition, the good faith defense was irrelevant. Accordingly, it issued a cease and desist order.

\section{The Standard Oil (Indiana) Order}

The substance of the Commission's order was as follows: (1) Standard must stop selling to some retailers at prices less than those it charged other retailers; (2) Standard must not allow lower prices to jobbers on that part of the gasoline which the jobbers sold at retail; and (3) Standard must not allow a lower price to a jobber where the jobber resells to retailers at a price below Standard's tank wagon price.

The prohibitions in the order were limited, however, to discriminations affecting competition between retailers of Standard gasoline who were in actual competition with one another. They were further limited to discriminations not justified by differences in costs, since Subsection 2 (a) clearly exempts such discriminations.

The United States Circuit Court of Appeals for the 7th Circuit modified the Commission's order somewhat, but unanimously upheld the Commission's main contention, which was that good faith does not immunize a discriminatory practice after the practice has been shown to have the harmful effects on competition specified in the statute. In reaching this decision the Circuit Court leaned upon the language of the statute and the legislative history of the Robinson-Patman Act. ${ }^{69}$

6838 Stat. 730 (1914), as amended, 49 Stat. 1526 (1936), 15 U.S.C.A. §13(a) (1951).

69 The Circuit Court said, "The Chairman of the House Conferees stated on the floor of the House as he presented the Conference Report:

"It is to be noted, however, that this does not set up the meeting of competition as an absolute bar to a charge of discrimination under the bill. It merely permits it to be shown in 
Little objection has been raised against that part of the Commission's order which prohibits Standard from discriminating directly among competing retailers. It seems indisputable that its order would be ineffective if Standard were allowed to accomplish the same result through the medium of a jobber. Yet it is this latter feature of the Commission's order which has been used as the basis of the assertion that the Commission has launched a crusade to eliminate wholesalers. When the Circuit Court of Appeals was confronted with the argument that the effect of the Commission's order was to eliminate wholesalers, it made a reply which should have directed the subsequent argument along logical channels. It said: The petitioner argues that this is an elimination of wholesalers. If this be true, it is elimination only where their existence cannot be justified except on the exploitation of a differential in price not justified by any cost savings to obtain that price. This does not impress us as either illegal, unwarranted, or unjust. ${ }^{70}$

Thus, a logical rebuttal to the Circuit Court's decision-should anyone care to make it-would be to this effect: $A$ wholesaler has a right to a margin for which he serves no economic function, and this right is paramount over both the rights of injured parties and the public interest in maintaining a competitive system. Such an argument would have faced the issue squarely. But the appearance of an intermediary, or "jobber," in the trade picture introduces a complication which provides an added opportunity for shifting the argument to quite different grounds.

The argument offered, though without an explicit statement of the causal relationships, is that discrimination in the Detroit area was the very essence of competition-indeed the cause of competition. Conversely,

evidence. This provision is entirely procedural. ... If this proviso were construed to permit the showing of a competing offer as an absolute bar to liability for discrimination, then it would nullify the act entirely at the very inception of its enforcement, for in nearly every case mass buyers receive similar discriminations from competing sellers of the same product....

"The intent of Congress is clear and the language used to express its intent, it seems to us, is not ambiguous. That Section 2(b) is as the Conference Report says it was intended to be, seems to be the view of the Supreme Court as expressed in Federal Trade Comm. v. A. E. Staley Mfg. Co., 324 U.S. 746, 65 S.Ct. 971, 89 L. Ed. 1338, which reversed this Court in A. E. Staley Mfg. Co. v. Federal Trade Commission, 7 Cir., 144 F. 2d 221, wherein we held the prima facie case had been rebutted. Chief Justice Stone said, ...

"It will be noted that the defense that the price discriminations were made in order to meet competition, is under the statute a matter of "rebutting" the Commission's "prima-facie case." Prior to the Robinson-Patman amendments, $\$ 2$ of the Clayton Act provided that nothing contained in it "shall prevent" discriminations in price "made in good faith to meet competition." The change in language of this exception was for the purpose of making the defense a matter of evidence in each case, raising a question of fact as to whether the competition justified the discrimination.' "Standard Oil Co. v. FTC, 173 F. 2d 210, at 215-16 (C.A. 7 th, 1949).

70173 F. 2d 210 (C.A. 7th, 1949). 
so the argument goes, the Commission's order seeking to restrain discrimination would restrain competition and force consumers to pay higher prices. This is an argument which manifestly has great appeal to the courts and accords with their established predilections in such matters.

But did Standard's discriminations increase competition and did they result in lower prices for consumers in Detroit? Conversely, would consumers in Detroit pay higher prices for gasoline if Standard were compelled to comply with the Commission's order? Perhaps the best way to answer these questions is to begin by asking another question: "Why did Standard make the discriminations in the first place?" Surely Standard was not merely trying to compete with itself.

Standard shared in the Detroit market with several of the other major oil companies. The record indicates that there was little or no price competition between the majors. There appears to have been no competition at all in the majors' tank wagon price (the price at which most of the gasoline was sold) although evidence was introduced to show that other majors had on occasion offered Standard's "jobbers" gasoline at prices as low or lower than Standard's. Standard was the price leader.

So far, the facts would seem to present the typical picture of gasoline marketing over the country. In some further respects, however, the Detroit market was perhaps atypical. The majors altogether sold about 87 per cent of the gasoline consumed in the area, while independents supplied the rest. The relatively high proportion of non-major brand gasoline sold in the Detroit market seems to have been accounted for by the fact that there were several independent refiners in Michigan, refining Michigan crude, with relatively easy access to Detroit by water freight. The nonmajor gasoline sold at retail below the price of major brands. The usual differential of 2 cents a gallon appears not to have diverted much trade from the stations selling major brands, but when the price of non-major brands dropped below a 2 cent differential, major sales dropped and independent sales increased. At times the independents' prices dropped as much as 6 cents below the price of major brands, and there were frequent "price wars" in the area.

The trouble, it appears, was caused by a small Michigan refinery named Red Indian. It seems that Red Indian was willing to take a lower price for its gasoline than Standard charged. Having itself neither storage nor distributing facilities in the Detroit area, there were few buyers to whom it could effectively offer its gasoline. Standard therefore discriminated to meet Red Indian's offers to these particular buyers. Since these buyers had a choice between Standard's highly-advertised gasoline and a less-known 
gasoline, both at the same effective price, they naturally chose the advertised brand. The result was that the smaller refiner was foreclosed from the Detroit market.

This situation poses the general problem: What chance is there for a small seller to break into the market against the discriminatory tactics of a large competitor? Should Red Indian go elsewhere to find a market? Where would it go, if it is to be met with the same obstacle in market after market across the country? Should it invest in its own storage and distribution facilities and in its own retail stations? If it has only enough capital to acquire such facilities in a few selected areas, then would it not be squeezed out by discriminations in whatever areas it made its investments? Could Red Indian anywhere reduce its price sufficiently below the major competitor's price to take any substantial business? Or would it not always find its prices met by discriminations and, inevitably, conclude that it has all to lose and nothing to gain by attempting price reductions?

\section{Standard Oil's Alternatives}

What would be Standard's alternatives under the Commission's order? First, if it wished to exclude Red Indian from the Detroit market, it might reduce its price to all buyers in that area. True, this would prove less profitable to Standard, as it would result in lower prices to consumers throughout Detroit, not just to those consumers who found it convenient to patronize the retail outlets enjoying the discriminatory advantage. Alternatively, however, suppose that Standard chose to maintain its general price level in the Detroit area. Then it would have to refuse discriminations to jobbers whom it knew to be reselling at prices below Standard's prices to competing dealers. Since these jobbers have demonstrated a desire to increase their shares of the market, by passing on lower prices, it can be assumed that they would now seek suppliers offering low but non-discriminatory prices, which they could pass on to consumers. The same consumers who formerly purchased gasoline at a low price would still have gasoline available at a low price, but it would be purchased from the independent refinery.

Assuming that the independent refiners who have already demonstrated their willingness to sell below Standard's prices can and do produce gasoline equally as good as Standard's, their products would gain consumer acceptance and gradually cut into Standard's sales. This might force Standard's whole price level down-an eventuality which Standard undoubtedly foresaw when it deployed its prices so as to make the distribu- 
tion facilities of the four "jobbers" unavailable to Red Indian and other independents. ${ }^{71}$

Obviously, of the several alternatives open to Standard, the one offering the greatest profit and market security was the one which it chose. This course also resulted in the highest average price to consumers, the lowest opportunity to smaller refiners, and the destruction of independent retailers. But the destruction of independent retailers would be of little consequence to a major oil company. Indeed, if independent retailers go bankrupt, their stations can be brought up to further insure against a small refiner ever finding market outlets.

In summary, the effects of the discriminations in the Detroit area were to block the entry and growth of small refiners and, at the same time, to maintain high prices for major brand gasolines. Conversely, any realistic course which Standard might have taken in obedience to the Commission's order would have had the opposite effects. Mr. Simon painted a much different picture of this matter to the Supreme Court. He told the Court that the Commission's order in this case was an attempt to protect competitors from competition, "the N.R.A. theory," and that the Commission's "phi-

${ }^{71}$ Another reason which has been suggested for the discrimination is that Standard adopted this means of forcing its dealers to reduce their margins and thus bear the burden of driving out the independents. This is not implausible, and if true, was an additional way Standard used its power to force out independent competitors at a minimum of expense to itself.

Still another explanation was offered by counsel speaking as an amicus in the first oral argument of the Standard Oil case in the Supreme Court. This was to the effect that Standard's discrimination was intended to force down dealer margins, so that tank wagon prices could then be raised "without pushing the retail price above what the public was accustomed to paying previously." Brief for Retail Gasoline Dealers Association of Michigan, Amici Curiae at 17, Standard Oil Co. v. Federal Trade Commission, 340 U.S. 231 (1951). Such may indeed have been a part of the purpose of the discrimination. If true, however, this would imply a degree of monopoly control over the market which further suggests the need for competitive rules which would allow newcomers to break in to the market.

This point brings to mind a somewhat different matter. Students who have read this paper in draft stage have raised this question concerning our general analysis of discrimination: "What about other traditional kinds of analysis, e.g., a monopoly exploiting independent markets to the fullest extent?" The answer is quite simple. Different groups of buyers frequently have different demand curves. Consequently, we are fully aware that established monopoly can discriminate to key its prices to the different demand curves, to the benefit of both itself and consumers generally. We are not here dealing, however, with the rules of competition from the standpoint of which rules are most conducive to the creation and efficient operation of monopoly. On the contrary, the question here is "What kind of rules will best create and maintain competition?" It is apparent, we think, that rules of competition which shift the question of who is to survive the competitive struggle from the question of "who is the biggest" to the question "who is the most efficient" will tend to create and maintain competition. It may be said in summary however that the Clayton Act, as amended, does not interfere with discrimination by monopoly which has any legal sanction. 
losophy of the Robinson-Patman Act" was "diametrically opposed" to the philosophy of the Sherman Act. ${ }^{22}$

The Court must indeed have believed that it was injury to competitors that the statute meant to restrain, rather than a particular method by which competitors are injured. The majority opinion throughout treats discrimination as synonymous with competition and sets up as the basic question to be decided the question of how far Congress meant to go in restraining competition by passing the Robinson-Patman Act. The majority came to the conclusion that Congress manifestly did not intend to go so far as to stop competition (discrimination) in good faith, since Congress left an obvious loophole by which competitors might be injured-that is, non-discriminatory price reductions. It said: "It must have been obvious to Congress that any price reduction to any dealer may always affect competition at that dealer's level as well as at the dealer's resale level, whether or not the reduction to the dealer is discriminatory."73

Shortly after this decision was announced, there was introduced in the Senate the basing point bill, Sen. 719. Its "primary purpose," according to the accompanying report, is to "conform statutory law" with the Supreme Court's interpretation of the law in its Standard Oil decision. ${ }^{74}$

\section{Simon's Charges against the FTC}

Against this background of the issues we can now better understand Mr. Simon's charges against the Commission. These charges break down

72 The following colloquy is from the transcript of the oral argument before the United States Supreme Court in Standard Oil Company v. FTC, p. 49 (October 10, 1950):

"MR. Snron: Then it is generally the consumer that gets hurt.

"JUSTICE JACKSON: Do you think we have statutes of any consistent philosophy of business control?

"MR. Snron: Well, I must confess that the philosophy of the Sherman Act is diametrically opposed to the philosophy of the Robinson-Patman Act, as the Federal Trade Commission construes it.

"JUSTICE JACKSON: We have vacillated and oscillated between the N.R.A. theory, roughly, and the Sherman Anti-Trust Law theory ever since I can remember, and we are still wobbling.

"Mr. Snron: This is the N.R.A. theory and, Mr. Justice Black, it is no different than the hundreds of cases you have had in this court where a bunch of businessmen get together and say, 'We are just not going to compete with each other too roughly. I won't take any business away from you; you don't take any business away from me, and we will all live and let live.' "

${ }^{73}$ Standard Oil Co. (Indiana) v. FTC, 340 U.S. 231, 250 (1951).

74 "The primary purpose of this bill is to conform statutory law to the interpretation of section 2 of the Clayton Act, as amended by the Robinson-Patman Act (49 Stat. 1526, 15 U.S.C., sec. 13), recently enunciated by the Supreme Court in Standard Oil Company v. Federal Trade Commission, 340 U.S. 231 (1951)." Sen. Rep. No. 293, 82d Cong. 1st Sess. 1 (1951). For an analysis of the Standard Oil (Indiana) decision, see the minority report on Sen. 719 of the Senate Committee on the Judiciary, Sen. Rep. No. 293, 82d Cong. 1st Sess. Part II (1951). 
into three major headings: (1) that the Commission has failed to be informative; (2) that the Commission has created confusion; and (3) that the Commission's staff has crusaded for " "unorthodox' ideologies," some of which, if adopted, would put business in conflict with the Sherman Act.

\section{The Charge that the Commission Has Failed To Be Informative}

Mr. Simon castigates the Commission for its "refusal to be informative,"75 alleging that it wilfully refuses to assist businessmen to understand the law. He concludes from his study of the legislative history that the Commission has strayed from its original statutory duty by refusing to issue advisory opinions to businessmen with respect to the legality of possible courses of conduct under the antitrust laws. A similar complaint is made of the Commission's refusal to make formal acceptance or rejection of the business firms' compliance reports, which are filed after receipt of a cease and desist order.

In support of his interpretation of the legislative history of the FTC Act, Mr. Simon offers a quotation from President Wilson's message of January 20, 1914, from which an inference can be drawn that President Wilson envisioned a trade commission issuing advisory opinions and that the FTC Act was passed by Congress "acting upon that recommendation." ${ }^{\prime 76}$ It is probable, however, that one can find in the quotation cited at least an equal emphasis on the idea that the new commission was not to be "empowered to make terms with monopoly."

The Commission has been extensively informative to business. It has engaged successfully in trade practice conference work for the last thirty years. In this work it cooperates with whole industries in working out rules of fair conduct. Such trade practice rules have been worked out between the Commission and business firms for more than 166 industries. ${ }^{78}$ These rules are published and widely disseminated among businessmen, trade associations, consumers and others. This is in addition to the Commission's findings and orders which are published and indexed in the usual manner.

To write of the Commission's "refusal to be informative" states the complaint too broadly. What seems more nearly correct is that the Commission has refused to give the kind of information Mr. Simon wishes it to give. Both the House and Senate committees which passed on the FTC

${ }^{75}$ Simon, op. cit. supra note 2 , at 301.

76 Ibid., at 299.

7751 Cong. Rec. 1963 (1914), cited by Simon, op. cit. supra note 2, at 299, n. 5.

78 FTC, Annual Report 69 (1950). 
bill studied the question whether the Commission should be authorized to give advisory opinions, and these committees heard many qualified persons on the subject. Among those heard was Louis D. Brandeis. Shortly after its formation, moreover, Brandeis advised the Commission on the same subject. Brandeis' interpretation of the legislative history of the FTC Act differed from Mr. Simon's:

It never was intended, in the composition of the Board, and certainly not in the legislation, for you to exercise this power. That was very much discussed, and the only strong argument that was put up against the Trade Commission was the danger of giving to the Commission just such power as this. ${ }^{79}$

Brandeis' advice to the Commission did not rest merely upon his opinion that the Commission was not intended and did not have the authority to issue advisory opinions; he also added a strong logical argument as to why such a practice would be unworkable. ${ }^{80}$ One of the sources of dissatis-

${ }^{79}$ FTC Records, Testimony before Commission of Louis D. Brandeis at 4 (1915).

${ }^{80}$ A more complete statement of Brandeis' comments to the Commission is as follows:

'Mr. BRANDEIS: That question which they bring up is a question which has been very much discussed as, on the one hand a thing that was desirable, and, on the other hand, as a thing that was dangerous. ... From the business standpoint, it is desirable. It would be a very convenient thing if a man could come before your body and say, 'Here are the facts; is this right? Can we do this, or can we do that?' It sounds very alluring. I believe it to be absolutely impossible of proper application, and for this Commission, I think it would be one of the most dangerous powers that it could possibly assume. Now, take this situation. In the first place, whether a thing is within the prohibition of the law, or is not, is a legal question. Ultimately, it has got to be decided, if the question does come up, by the Supreme Court of the United States. . . . It never was intended, in the composition of the Board, and certainly not in the legislation, for you to exercise this power. That was very much discussed, and the only strong argument that was put up against the Trade Commission was the danger of giving to the Commission just such power as this; that it was almost inevitable that if that power were given the public would be tricked; I mean, that the Commission, with the best of intent, would be hoodwinked; and it is really inevitable that it should be. . . . The difficulty in this situation of you passing upon this condition is twofold. In the first place, the facts do not exist yet. You are to determine in advance, largely as prophets, what is going to happen. Assuming absolute good faith on the part of the people who come before you, you are to determine whether that which they are planning to do is going to result in an improper restraint of trade. You cannot decide that fact because you do not know what the facts are going to be, nor the conditions to which they are going to apply them, because they do not even know; because they are going to act, and even in good faith, upon the circumstances as they arise from time to time. ...

"But the other point is, and that is the point that we lawyers have to deal with more frequently, and which is constantly impressed upon us, no statement of facts, however honest your people may be, can be relied upon until it has been subjected to the careful study and criticism of people who have a different point of view. Now, these people may be perfectly honest in laying this matter before you. They see it from their side. They do not know the whole field. They only see the difficulties which they have got and which they are trying to overcome.... If we are going to get anywhere near the truth and justice in this action you have got to have the other side fully represented, and that never can be done in advance because the people who are going to be affected by this are not available. ...

"Now, I do not believe, on the other hand, that the difficulty for the business man is nearly as great as he imagines it to be. $I$ have been at times counsel for a few trusts. The president of one of the largest of them, when we were discussing the law some four or five years 
faction with the Sherman law was the practice of executive sanctions, not infrequently conferred upon highly dubious business deals. Consequently, two antitrust agencies, each granting businessmen immunities from the laws of the other, was hardly the purpose Congress had in mind when it passed the FTC Act. As Brandeis' remarks suggest, considerable opposition to the proposed Commission was engendered by the fear that it might somehow sanction unsound business practices, with the effect of immunizing them from the Sherman law. It was for this reason that Congress adopted Section 11 of the FTC Act, providing that nothing in the Act "should be construed to prevent or interfere with the enforcement" of the antitrust acts. ${ }^{81}$

The same practical objections and the same question of legal authority apply to the Commission's blessing compliance reports as apply to the giving of advisory opinions in the first place. The problem whether an order of the Commission has been violated would seem to raise a sufficiently knotty question for litigation, without adding to it the further

ago,-and he was full of his attacks against the Sherman Law,-said to me, 'Now, you have been speaking in favor of this Sherman Law, and I have been going around and trying to find out what I can do, and I can't get any advice as to what I can do.' And he said, in rather a pleasant enough way, but in certain ways rather sneering, 'Perhaps you can advise me.' I said, 'I can advise you perfectly, but it is a question of what advice I can give you. If you ask me how near you can walk to the edge of a precipice without going over, I can't tell you, for you may walk on the edge, and all of a sudden you may step on a smooth stone, or strike against a little bit of root sticking out, and you may go over that precipice. But if you ask me, how near you can go to the precipice and still be safe, I can tell you, and I can guarantee that whatever mishap comes to you, you will not fall over that precipice. You have taken my advice, and other lawyers' advice about any number of things; and when we give you advice, you act on that advice; and you have given up many a good trade on questions that have had nothing to do with the Sherman Law, at all, because you were not willing to take the risk.' ... I said, 'You must not expect from the Sherman Law any more than you do from any other law you are dealing with. You must not expect that you can go to the verge of that law without running any risks. Why should you? You do not in any other relation of life that $I$ know of. And your lawyers, if they are good lawyers, and experienced lawyers, can advise you. As a matter of fact, there have been mighty few relations in life where you could not have advised yourself. Your conscience, if you are honest with yourself, would tell you, nineteen times out of twenty, and without a lawyer, whether you intended to restrain trade; and if you could say to yourself, clearly, and honestly, that you did not intend a restraint of trade, you would not need to go to any lawryer at all. But if you want to know whether you can squeeze through, -or something comes up that suggests to you that there is a very grave doubt that you can squeeze through, then you want to get some way to squeeze through.' I feel that very strongly from the experience that I have had. I think there are a good many things-quite a number of things that men have been frightened from doing which, under courageous advice, they could do; a great many agreements which I believe would be held reasonable.

"So, I believe, that this Commission could not do anything which in its real essence, would be more harmful to business, and more dangerous to the Commission itself, than to exercise this power, if you have it. But I think it is perfectly clear that you have not got it." Ibid., at 2-9, 12-13.

8138 Stat. 717 (1914), 15 U.S.C.A. $§ 51$ (1951). 
questions (1) whether business firms have, by their statements, correctly interpreted the Commission's order, and (2) whether the Commission has correctly interpreted the business firms' interpretation of its order.

\section{The Charge that the Commission and Its Staff Have Caused Confusion}

Granted, there has been a great deal of confusion, but it is abundantly clear that the bullk of this confusion was artificially generated by industry interests affected. Here it may be admitted that the two antimonopoly laws in dispute are not models of clarity. On the contrary, all the antitrust laws are probably not semantically precise. But it is quite doubtful if clarity in the antitrust laws is desired by those now attacking them, particularly if clarity is to be coupled with strength.

A general clarification of the law on the basing point system without weakening our antitrust policies would not require a difficult feat of draftsmanship. The law could be clarified with fewer words than would go into an ordinary telegram. All that would be necessary is a law which declares that the basing point system is illegal. Such a statute, coupled with Mr. Justice Black's description of the basing point system in the Cement opinion, would make the matter crystal clear. This description is a monument of simplicity and clarity in expository writing. Any businessman can read it and know what the basing point system is. And businessmen who are not desirous of skating on the last possible brink of legality can determine what it is they should avoid without advice of counsel. This is about what the state of the law on basing points was after the Cement decision. But as Professor Latham has said:

It is difficult, if not impossible, to ascertain with exactness the intention of the steel industry in this matter, but there is certainly a sense in which it could be argued that the trouble with the existing law was not that it was unclear, but that it was becoming painfully clear, and that the hope of practitioners of the basing point system was not to clarify the trend, but to reverse it..$^{82}$

\section{The Charge that the Commission's Staff Has Crusaded for " 'Unorthodox' Ideologies"}

Here we come, judging by the vigor of his language, to what is $\mathrm{Mr}$. Simon's main argument against the Commission. But we find the thread of this argument somewhat elusive for the reason that he seems not quite to have made up his mind whether the burden of his complaint is (1) that there is duplication of activity between the FTC and the Department of Justice because "the same statutes may in effect be enforced against the same businessmen"83 or (2) that although there is "virtually concurrent

82 Latham, op. cit. supra note 47, at 273.

${ }^{83}$ Simon, op. cit. supra note 2, at 297. 
jurisdiction," 84 the FTC staff has refused to enforce the laws as promulgated by Congress but has instead crusaded for " 'unorthodox' ideologies." 85

Taking Mr. Simon's article as a whole, however, it seems safe to say that the "crusades" for " "unorthodox' ideologies" are what he objects to most. They are, to use Simon's phraseology: (1) the crusade for "f.o.b. mill"; ${ }^{86}$ (2) the crusade against "functional pricing"; $; 8$ and (3) the crusade against "good-faith competition."

It is now a well-advertised fact that the late Walter Wooden, long-time Associate General Counsel of the Commission, and the man who handled most of the Commission's basing point cases, at one time endorsed an "unorthodox" solution to the basing point controversy. In the bitter debates that followed the Cement decision, the basing point advocates would recognize no middle ground for independent or individual delivered prices. Their argument was that either the law permitted all of the characteristics of basing point price-fixing; or it required unvarying f.o.b. mill. After many months of this, Mr. Wooden announced that he would personally recommend legislation requiring f.o.b. mill. Mr. Wooden made it very clear, however, that he understood existing law to make no such requirement.

The crusade against "functional discounts" appears to be mainly the Commission's attempts to enforce the antidiscrimination statute in the Standard Oil case ${ }^{89}$ and in the Spark Plug cases..$^{90}$ It is evident by now that this is purely a problem of semantics. Just as attempts to restrain basing point conspiracies have been labelled "crusades for f.o.b. mill," any discrimination cases which happen to involve business firms in different trade levels now become crusades against "functional pricing."

The Chairman of the Commission in an address to the annual meeting of the Motor and Equipment Wholesalers Association on December 3, 1951, stated:

As Chairman of that Commission, however, I am in a position to assure you that the Commission has never issued an order to cease and desist in a price discrimination case under the Clayton Act, as amended by the Robinson-Patman Act, against a manufacturer forbidding the granting of functional or trade discounts as such. So much for the past. As to the future, I can assure you as Chairman of the Commission that I have no thought of attempting any such action and in my judgment the law would not permit the Commission to take such action. ${ }^{21}$

84 Tbid.

87 Ibid., at 307.

${ }^{85}$ Ibid., at 298.

${ }^{88} \mathrm{Ibid}$., at 315 .

${ }^{85} \mathrm{Ibid}$., at 302.

89 Op. cit. supra note 6 .

${ }^{20}$ Authorities cited note 5 supra.

21 Mead, Address to Motor and Equipment Wholesalers Ass'n (December 3, 1951). 
In view of such clear statements from the Chairman and others, it would seem sensible to wait and hear the Commission's side of the Spark Plug cases before passing judgment on Mr. Simon's argument that the Commission has launched a campaign to eliminate wholesalers from the business system.

The Commission's stand in the Standard Oil case also supplies the "proof" of its crusade against "good faith competition." As has already been noted, the Commission took the position that since Standard's practice of discriminating in prices was injuring, and probably destroying, several hundreds of its independent retail distributors, the practice should be stopped even though it might have been carried on in "good faith." The opponents of this position would place a higher value on "good faith" than upon an antitrust law which could restrain destructive abuses of power.

VI. Simon's Legislative Recommendations

Mr. Simon's legislative recommendations are to transfer the FTC's antitrust functions to the Department of Justice, to make the Commission's findings of fact subject to review on the weight of the evidence, and to transfer the FTC Bureau of Industrial Economics to the Department of Commerce.

\section{The Independent Regulatory Commission versus the Executive Agency}

If the proposal to transfer the Commission's antitrust function to the Department of Justice were adopted, then Mr. Simon's recommendation of having the courts review the Commission's findings "on the weight of the evidence" would become surplusage. The district courts make findings of fact "on the weight of the evidence" in Justice cases, in the first instance. On the other hand, the recommendation that the courts be required to review the Commission's findings on "weight of evidence" overlooks the reasons why a regulatory body was created in this field in the first place. Mr. Landis has said of these reasons:

In the field of unfair competition and monopoly, and in the field of labor, there was widespread distrust of the courts' ability to evolve workable concepts to direct the economic forces which had posed these problems. Some of this distrust found its source in the belief that the resolution of these matters required a condition of uninterrupted supervisory interest that was incompatible with the demands of judicial office. ${ }^{22}$

Mr. Simon would turn back the clock nearly forty years. He seeks a return to conditions which prevailed before President Wilson and Congress resolved the issue of monopoly regulation. As early as 1911, Attorney General Wickersham had recommended an administrative agency such

${ }^{22}$ Landis, op. cit supra note 8 , at 32-33. 
as the FTC to supplement his department's work in the antitrust field. ${ }^{93}$

Mr. Wickersham's frank admission about the inadequacy of the Department of Justice in controlling the monopoly problem is supported by Mr. Landis, ${ }^{94}$ and Professor Robert E. Cushman, one of the most highly regarded authorities on this subject, has also pointed out the disadvantages of partisan control over the enforcement of antimonopoly laws. ${ }^{95}$

Recent rapid changes in the office of the Assistant Attorney General in Charge of the Antitrust Division of the Department of Justice demonstrate Cushman's point all too clearly. Within the past ten-year period six different men have had the job of administering the Sherman Act. ${ }^{96}$ It would thus appear that both past experience and experts in the field oppose the notion of returning the regulation of competitive methods to the sole jurisdiction of an executive agency and the courts.

\section{Sherman Act Cannot Replace the More Modern Laws}

The Sherman Act is now enjoying a period of popularity with certain business groups who are centering their efforts upon destruction of the FTC and Clayton Acts. The Sherman Act is held up as the staid and respectable guardian of the competitive way, while the two newer laws are condemned as going in the opposite direction-at least as these later laws are interpreted by the Commission's "administrative policies."

The really interesting aspect of this turn of events is not so much that the Sherman Act was under more or less constant attack by many of the same business groups during the first forty or fifty years it was on the books, but that the same argument was previously advanced against this law. While it is now argued that the philosophies of the FTC and Clayton

9351 Cong. Rec. 11094 (1914). Speech given at Duluth, July 19, 1911.

94 Landis, op. cit supra note 8, at 32-33.

${ }^{9}$ Cushman, The Independent Regulatory Commissions at 181-90. Professor Cushman further states:

"Stability and continuity of service were bound to be important elements in the make-up of the proposed commission. These could be secured only if that body was independent of direct political control. The uncertainties arising from the fluctuations in policy in the Attorney General's office with reference to the enforcement of the antitrust law had been a major reason for the proposal to set up a commission. The men in office charged with law enforcement this year would be gone next year, and the business world had nothing stable or reliable to tie to. With an independent body whose members held for substantial and overlapping terms of office, continuity of policy and stability of administrative method could be built up. In no other way could there be secured the "continuous, consecutive, consistent administration of the antitrust law." "Ibid., at 192.

${ }^{96}$ The following men have held that post: Thurman Arnold, Tom Clark, Wendell Berge, John F. Sonnett, Herbert A. Bergson, and H. Graham Morrison. All but two left federal service to engage immediately in private law practice and some have become representatives of organizations or firms charged with violations of the antimonopoly laws. 
Acts are antagonistic to the Sherman Act, it has previously been argued over the years that the philosophies of the Sherman Act itself went in opposite directions at once, and that the Sherman Act was antagonistic to itself. This earlier "antagonism" argument made-no doubt unwittingly-as strong an argument as any for the very rules of fair competition which are provided in the FTC and Clayton Acts.

For a really artful development of the argument that the Sherman Act is itself inconsistent, one should turn to the hearings of the Stanley Committee of 1911, and read particularly the testimony of Mr. Gary, a gentleman under whose leadership the U.S. Steel Corporation developed a high degree of harmony with its competitors. ${ }^{97} \mathrm{Mr}$. Gary told the Committee that it was "his position that the Sherman anti-trust law recently interpreted by the Court nevertheless leaves an archaic law to deal with the modern situation." Thereafter, he developed in some detail the contention that the Sherman Act's prohibition "against restraint of trade" was antagonistic to its other prohibition "against monopoly," forcing competitors into price wars which result in monopoly. In this instance, Mr. Gary's objection was not to the prohibition against "monopoly," but to the prohibition against "restraint of trade." He suggested that unless competitors were permitted to "enter into any combination or agreement, express or implied, to fix prices, to restrict output, to divide territory. . . . except for some basis whereby destructive competition could be avoided... it would mean that a large percentage ... of the manufacturers of steel would be wrecked; and that would secure to the survivors, to a greater or less extent a monopoly." 98

Here it must be plain that Mr. Gary was not merely justifying the "Gary Dinners," at which competitors in the steel business reached a certain meeting of the minds concerning prices. He was also condemning, perhaps unwittingly, the destructive trade practices then in general use. One of the most destructive of these practices, as subsequent events have shown, was the discrimination which the Clayton Act and the RobinsonPatman Act have sought to control.

Sherman Act Proscribes Evil Intent but Not Bad Practices

The late Professor Frank A. Fetter, whose views were criticized by $\mathrm{Mr}$. Simon, contended that the Sherman Act, "if soundly interpreted and en-

${ }^{97} 4$ Hearings before the H.R. Committee on Investigation of U.S. Steel Corp., 62d Cong. 2d Sess. 151 (1911).

${ }^{98}$ Ibid., at 195. 
forced," would make discrimination about as illegal as it is under the Clayton Act. ${ }^{99}$ But the conditional "if" is a formidable one indeed. True, if the courts had originally looked upon discrimination as a prima facie "attempt to monopolize," instead of burdening the law with the question of intent, the law of 1890 might have become an effective instrument for restraining abuses of power. But a contrary notion of the purpose and desirability of discrimination has long since been established in the legal folklore. And

- once the courts have hit upon an economic predilection, they are not without ingenuity for preserving it, even to the extent of invalidating new statutes which trespass on their precepts. There have appeared occasional glimmers of understanding into the effects of discrimination, particularly in the opinions of Justice Black and the late Chief Justice Stone, but for the most part the notion is fixed: What restrains particular methods of competition also restrains competition.

As late as 1927, long after passage of the Clayton Act, the Supreme Court invalidated a state law which sought to control price discrimination. The state of Minnesota had in 1909 enacted a statute prohibiting discrimination when "done with intent of creating a monopoly or destroying the business of a competitor." The law having proved a general failure, as qualified by intent, the legislature in 1923 amended it by removing this qualification. Statutes against acting with wrong intent had of course been uniformly sustained. And the question which was put before the Supreme Court, under the modified statute, was whether a statute against discrimination, irrespective of motive, impaired the right of freedom of contract as guaranteed by the Constitution. In Fairmont Creamery Co. v. Minnesota, ${ }^{100}$ the Court held that it did. The reasoning of the majority opinion written by Justice McReynolds is quite interesting. Here discriminatory prices are called "normal contracts," "long regarded as essential ... and moral and beneficial." And finally, the Court concluded that an effective prohibition against discrimination would amount to price fixing. ${ }^{100 \mathrm{a}}$

\section{Robinson-Patman Act Needed To Stop Harmful Effects}

In the Standard Oil case the Supreme Court invalidated much of the Robinson-Patman Act on quite similar grounds. The majority opinion

99 Fetter, Masquerade of Monopoly 397 (1931). The reference was to the Clayton Act before the Robinson-Patman Act amendment.

${ }^{100} 274$ U.S. 1 (1927).

${ }^{100 a}$ The Court said: "TEnforcement of the statute would amount to fixing the price at which the [central creamery] may buy, since one purchase would establish this for all points without regard to ordinary trade conditions." Ibid., at 9. 
takes note that "there has been widespread understanding" that good faith is a complete defense to a charge of price discrimination, and that "the heart of our national economic policy long has been faith in the value of competition. ${ }^{101 "}$ "Judicial note is also taken of the fact that "[i]t has been suggested that, in theory, the Robinson-Patman Act as a whole is inconsistent with the Sherman and Clayton Acts." And finally, when it is decided that none of the changes made by enactment of the Robinson-Patman Act "cut into the actual core" of the good faith defense, there follows: "Actual competition, at least in this elemental form, is thus preserved." The minority opinion, moreover, while it could not accept the idea that all of the Robinson-Patman amendments to the good faith defense had actually left the defense unchanged, indicates similar beliefs concerning the competitive effects of discriminations.

Insofar as the law restraining discrimination is concerned, Mr. Simon's proposal to transfer the antitrust functions of the FTC to the Department of Justice suffers from two weaknesses. First, he would have the courts make findings of fact on questions as to effects of discrimination-a task the courts are patently not prepared to undertake. Second, if Mr. Simon's proposal contemplates dealing with discrimination under Section 2 of the Sherman Act, then he would return the whole problem of discrimination to the dark ages of regulating evil intent. Congress recognized the futility of such regulation in 1914 when it abandoned the question of motive and began proscribing harmful business practices by reason of the practical effects of those practices.

\section{The Proposal To Transfer FTC Economic Functions to the Department of Commerce}

The recommendation for transferring the FTC's economic functions to the Department of Commerce has apparently been made without an adequate effort to lay a groundwork for it by discussing the nature of these activities and the effectiveness with which they are presently being performed. The FTC's Bureau of Industrial Economics uses approximately half of its total expenditures for assistance in the preparation and trial of legal cases of an antimonopoly nature, or the type of cases that Mr. Simon

101 Op. cit. supra note 6 . In the Standard Oil decision the Supreme Court also engrafted several new concepts into the Robinson-Patman Act. For example, it reversed a normal legal concept concerning self-defense against an illegal attack, making use of the proscribed weapons legal in attack upon competitors eschewing such weapons. Then, by misapplication of the decision in the Staley case, it sought to reconcile this anomaly by drawing a distinction between discrimination for the purpose of "retaining" a customer and that for "gaining new customers" -a distinction which is both unworkable and alien to the competitive concept. See the minority views on Sen. 719, in Sen. Rep. No. 293, 82d Cong. 1st Sess. Part 2 (1951). 
would like to see transferred to the Department of Justice. ${ }^{102}$ The transfer of this part of FTC's economic activities to the Department of Commerce would hardly make sense, even assuming that Mr. Simon's other recommendations were to be adopted. The larger part of the remaining FTC funds for economic work - more than one-fourth - are spent upon quarterly financial reports. ${ }^{103}$ Current estimates of business profits are relative newcomers to the realm of official statistics. For many years public issues have been debated in light of facts as to trends in wages, cost of living, and other matters, but reasonably current facts on business profits were strangely missing. During the time these reports have been made, since World War II, they seem to have gained considerable popularity with business firms as with others.

The remaining portion of FTC's funds for its Bureau of Industrial Economics-about one-fourth of the total-are spent upon what Mr. Simon has termed "economic treatises." 104 He says that these treatises are compilations of statistics previously issued by the Department of Commerce. However, it appears that during the past three years there has been only one report which relied at all upon Department of Commerce figures, namely, The Divergence Between Plant and Company Concentration..$^{105}$ This report organized Commerce data to answer questions which the Department had, quite naturally, never answered.

The other economic reports have been based in part upon the Commission's Webb-Pomerene Act files, in part upon antimonopoly proceedings, in part upon direct investigations by the Commission, and in one instance upon published lists of corporate directorates. ${ }^{106}$

Economic investigation is the center of the Commission's work, and the specific provisions therefor in the FTC Act indicate that Congress so anticipated. ${ }^{107}$ To illustrate, investigations and studies of great economic and

${ }^{102}$ The estimates herein on the cost of the FTC economic activities are based upon information supplied by the FTC Budget Officer.

${ }_{102}$ Ibid.

104 Ibid.

${ }^{105}$ FTC, Annual Report 16-18 (1950).

${ }^{106}$ The Commission's Annual Report for 1948 lists four economic reports: The Merger Movement, International Steel Cartels, International Electrical Equipment Cartel, and Manufacture and Distribution of Farm Implements; the 1949 Annual Report lists two: Concentration of Productive Facilities and The Fertilizer Industry; and the 1950 Annual Report lists four: The Divergence Between Plant and Company Concentration, Interlocking Directorates, International Cartels in the Alkali Industry, and Rates of Return for 529 Identical Companies in 25 Selected Manufacturing Industries, 1940, 1947-49.

${ }^{107}$ Section 6, 38 Stat. 721 (1914), 15 U.S.C.A. $\$ 46$ (1951). The Hoover Task Force Report on Regulatory Commissions, whose comments with respect to the FTC have been previously 
legal problems were successfully carried through by the Commission, after which Congress passed such legislation as the Webb-Pomerene Export Trade Act of $1918 ; ;^{108}$ Grain Futures Act of $1921 ;^{109}$ Perishable Agricultural Commodities Act of $1930 ; 110$ and amendments of 1937; $; 11$ Radio Act of $1927 ; ;^{112}$ Securities Act of $1933 ; ;^{113}$ Public Utility Holding Company Act of $1935 ; ;^{114}$ Federal Power Act of $1935 ; ;^{115}$ Robinson-Patman Act of $1936 ; ;^{116}$ and the Anti-Merger Act of $1951 .{ }^{117}$ This important task of investigating economic problems should continue, if the American economy is to remain free, unfettered, and abreast of the times.

But this is hardly the kind of economic investigations which the Department of Commerce should make or would care to make. The Department of Commerce is a service agency to business, catering to the wishes of the community it serves. Its Bureau of the Census, for example, spends more than the combined budgets of the antitrust agencies in gathering statistics for the use of business firms in planning marketing and advertising campaigns. It is hardly likely that such service functions could be combined with the unpleasant task of revealing information on monopolistic practices. A transfer of FTC's economic functions to the Department of Commerce would stop such investigations.

\section{Conclusions}

The existence of a comparatively free and competitive economy distinguishes America from most of the other nations of the world. The economies of other nations which lack the regulatory force of competition attempt to supply this deficiency either by socialism or by government controls over the management of business. Such systems require the estab-

quoted herein, stated: "There is need for an economic staff systematically surveying our economy; probing for industrial and economic practices which threaten the elimination of competitive conditions; identifying restrictive tendencies before they become too solidly entrenched; analyzing the basic disorders found and formulating methods for their practical correction." H.R. Doc. No. 116, 81st Cong. 1st Sess. 124 (App. N., 1949).

10840 Stat. 516 (1918), 15 U.S.C.A. $\$ 61$ (1951).

${ }^{109} 42$ Stat. 998 (1922), 7 U.S.C.A. \$ 1 (1939).

11046 Stat. 531 (1930), as amended, 7 U.S.C.A. $\$ 499 \mathrm{a}$ (1939).

i11 50 Stat. 725 (1937), as amended, 7 U.S.C.A. $\$ 499 \mathrm{a}$ (1939).

11244 Stat. 1162 (1927), 47 U.S.C.A. $\$ 81$ (1927).

11348 Stat. 74 (1933), as amended, 15 U.S.C.A. $\$ 77$ a (1951).

11449 Stat. 803 (1935), as amended, 15 U.S.C.A. $\$ 79 \mathrm{a}$ (1951).

11549 Stat. 863 (1935), as amended, 16 U.S.C.A. $\$ 791$ a (1941).

11649 Stat. 1526 (1936), 15 U.S.C.A. § 13 (1951).

${ }^{117}$ Pub. L. No. 899, 81st Cong. 2d Sess. (Dec. 29, 1950). 
lishment of complete detailed control over the economic lives of every citizen through a paternalistic government. The growth of monopoly power in the hands of private corporations in this country will lead inevitably to monopoly power in the hands of government officials, with a corresponding lessening of individual freedom.

The Department of Justice has in the Sherman Act both remedies in the criminal law and powers for dissolving monopolies which the FTC does not have. All of these powers are needed; both FTC and the Department of Justice are needed. Administration of the antitrust laws, both in the FTC and in the Department of Justice, leaves much to be desired. Several thoughtful and highly-qualified persons, interested in more effective enforcement of the laws, have offered criticisms. We do not question that these criticisms are valid. We cannot, however, agree that Mr. Simon's proposals would meet these criticisms. Nor can we avoid the observation that the FTC's present difficulties do not result so much from the measure in which it has failed to carry out its statutory duties as they do from the measure in which it has succeeded in carrying out its statutory duties.

We do not agree with Mr. Simon's proposals. We insist that the enforcement of the laws restraining unfair methods of competition and harmful price discrimination ought not be junked. Rather we believe that they should be strongly enforced and, where need be, strengthened. We insist that all pricing systems which effectively suppress competition ought to be stopped, not just those which can be proved to result from a contractual agreement.

We insist, equally, that abuse of size ought to be restrained, so that success or failure in the competitive struggle may be determined not by size, but by efficiency. It is only under such a rule of competition that smaller business firms can grow and prosper and that the door of opportunity can be kept open. 